\title{
INFOTAINMENT: KEBEBASAN ATAU KEBABLASAN DITINJAU DARI KAJIAN EKONOMI POLITIK MEDIA
}

\author{
Endang Setiowati \\ Jurusan Marketing dan Komunikasi, Fakultas Komunikasi dan Multimedia, Universitas Bina Nusantara \\ Jln. Kemanggisan Ilir III No.45, Kemanggisan, Palmerah, Jakarta Barat 11480
}

\begin{abstract}
Infotainment as delivered on television occurs to be one controversial TV shows, often accused as a program that practically a "Social Duping". But, in reality these genres frequently achieve rating peak, which in certain will raise TV commercial due to profitable matters for Television Company. Article explores "conspiracies" that occurs based on variable interest between producers, broadcasting industry, rating institutions, and advertisements both for continuity and multiple profit. The main idea of how infotainment dominates both news and entertainment program is caused by social actors' demands that implement in press liberating process in Indonesia whose embrace of neoliberalism which claimed that "the greater the play of the market forces, the greater the freedom of the press; the greater the freedom of the press, the greater the freedom of the audience choice". It seems impossible to stop infotainment programs since that alone will subdue both corresponding institution and individual in a certain point of view. Therefore, a regulation that copes with this matter due to continuity of these genres is needed in overcoming matters of "Social Duping".
\end{abstract}

Keywords: infotainment, freedom, vanish, media

\begin{abstract}
ABSTRAK
Infotainment yang ditayangkan sebagai acara yang kontroversial di TV sering disebut sebagai "Penipuan masyarakat", tetapi acara ini sering mencapai rating tinggi yang menyebabkan semakin banyak iklan TV yang masuk dan otomatis akan mendatangkan keuntungan perusahaan TV. Artikel menjelaskan konpirasi yang terjadi antara kepentingan produser, industri broadcasting, institusi rating, dan bagian iklan, baik untuk kepentingan kontinuitas dan keuntungan ganda. Ide utama infotainment mendominasi program berita dan hiburan disebabkan oleh tuntutan aktor sosial yang melaksanakan proses liberasi press in Indonesia, yang menganut neo-liberalism, yaitu "semakin besar peran pasar akan semakin besar kebebasan pilihan pemirsa". Tampaknya akan sulit untuk menghentikan program infotainment karena hal ini akan menindas perusahaan yang terkait dan perorangan dalam hal tertentu. Oleh karena itu, suatu peraturan yang terkait dengan masalah ini demi kelangsungan infotainment diperlukan untuk mengatasi penipuan masyarakat.
\end{abstract}

Kata kunci: infotainment, kebebasan, kebablasan, media 


\section{PENDAHULUAN}

Setelah selama lebih dari 32 tahun dikekang, perkembangan sistem pers Indonesia mendapatkan suatu titik balik, yaitu pada era reformasi, setelah keluarnya Undang-undang Pers No. 40 tahun 1999, yang dianggap sebagai Undang-undang Kebebasan Pers. Pers Indonesia seolah mengalamai euforia kebebasan memberikan aneka informasi pada publik. Demikian pula dengan publik yang biasanya harus mencuri-curi dengar informasi, yang dulu dianggap tabu untuk dibicarakan, kini menjadi haus akan segala informasi. Terbitnya Undang-undang Pers yang dikenal sebagai Undang-undang Kebebasan Pers ini memicu pertumbuhan organisasi media, baik cetak maupun elektronik. Dengan perkembangan organisasi media, maka mulai muncul persaingan dalam isi media untuk meraih pasar yang lebih besar. Media massa mulai mencari aneka isi media yang dianggap dapat menaikkan jumlah khalayak media mereka masing-masing. Berbagai topik mulai dari isu politik, sosial, publik hingga rumor para selebritas diungkap seolah kini tidak ada lagi hal yang dapat mengekang informasi apapun untuk diberitakan kepada publik. Khalayak yang haus akan informasi setelah puluhan tahun mengalami keterbatasan informasi juga mengalami euforia melalap segala informasi yang ditawarkan oleh media. Tidak ada batasan umur atau kelas sosial dalam mendapatkan informasi dari media massa.

Sistem pers yang kemudian dikenal sebagai sistem pers reformasi ini ditandai dengan kemerdekaan pers yang melahirkan suatu subsistem pers bebas, pers independen, pers investigatif, pers infotainment, pers hiburan, pers kriminal, dan sebagainya. Yang paling menonjol adalah munculnya subsistem pers infotainment, yang menampilkan acara berita dan informasi tentang selebritas, yang dikenal sebagai program infotainment, salah satu produk media televisi yang paling banyak ditonton orang, tetapi juga paling banyak dipermasalahkan. Infotainment sebenarnya muncul karena adanya tuntutan pemerintah agar televisi meningkatkan produksi program dalam negeri. Namun, maraknya kemunculan infotainment juga akibat semakin tajamnya persaingan di antara stasiun televisi dalam meraih pasar, karena televisi hidup dari iklan, sementara porsi iklan yang ada sangat terbatas, dibandingkan dengan jumlah media. Jadi, ketidakmampuan memproduksi tayangan dalam negeri dan adanya persaingan pasar membuat stasiun televisi kurang selektif dalam memilih program acara. Celakanya, program acara tentang pergunjingan sekitar rumah tangga para selebritas yang sarat dengan perselingkuhan, perceraian, perselisihan antara orang tua dan anak, dan lain-lain ini justru menyedot perhatian pemirsa. Lebih runyam lagi, acara sejenis ini justru meraih rating tinggi, yang otomatis dapat mengeruk perolehan iklan yang besar untuk keuntungan perusahaan media televisi. Dari kondisi ini, terjadilah "konspirasi" dari berbagai kepentingan antara produser, lembaga penyiaran, lembaga rating, dan pengiklan untuk saling menghidupi sekaligus mencetak keuntungan sehingga meski secara kualitas isinya tidak bisa dinilai baik, kolaborasi antara berbagai pihak itu tetap mempertahankan, bahkan menggenjot jumlah serta jenis infotainment untuk makin bertambah, dan mengepung seluruh sisi kehidupan kita.

Menurut Ketua Departemen Infotainment PWI, Hans Miller Banureah, ada tiga grup rumah produksi yang merajai dunia gosip di televisi, yaitu Bintang Grup yang hampir menguasai seluruh stasiun televisi menyebar program infotainment produksinya dengan berbagai nama program; Shandika yang merupakan rumah produksi kedua terbanyak mempunyai program infotainment di berbagai stasiun televisi; dan Indigo yang hanya mempunyai 3 jenis infotainment di 3 stasiun televisi. (Soemardjo, 2006: 4). Penguasaan program infotainment pada hanya tiga rumah produksi membuat isinya pada tiap stasiun televisi menjadi sama. Hal ini dapat mengakibatkan adanya homogenitas dalam informasi yang disampaikan oleh tayangan infotainment di berbagai stasiun televisi itu, yang akhirnya justru membentuk suatu selera pasar. Meski belakangan Trans TV membuat sendiri program infotainment dengan nama Insert, yang asalnya hanya satu kali sehari, tetapi kini bahkan ada 3 jenis, yaitu Insert Pagi, Insert Siang, dan Insert Sore, namun jenis informasi dan gaya penyajian yang disampaikan di ketiga jenis infotainment itu dan program sejenis di stasiun TV lainnya sama dan sebangun. 


\section{METODE PENELITIAN}

Artikel ini disusun berdasarkan studi pustaka, yaitu dari berbagai literatur dan berita yang diseleksi dan disintesakan menjadi karya tulis ilmiah ini.

\section{HASIL DAN PEMBAHASAN}

\section{Realitas Pasar - Selera Pasar}

Munculnya sistem pers yang lebih bebas di tanah air adalah akibat desakan para aktor sosial dalam proses liberalisasi pers di Indonesia. Hal ini dengan jelas didasarkan atas dogma neo-liberalisme yang antara lain mengklaim bahwa "the greater the play of the market forces, the greater the freedom of the press; the greater the freedom of the press, the greater the freedom of the audience choice" (Hidayat, 2003: 14-15). Dogma inilah yang diyakini oleh para fundamentalis pasar, baik di kalangan para pemilik modal sektor industri media, manajer media, atau bahkan di antara para jurnalis buruh media serta berbagai segmen konsumen media sendiri.

Para penganjur perspektif ekonomi-politik liberal di berbagai komunitas akademis juga meyakini proposisi bahwa liberalisasi atau deregulasi industri media di tanah air akan menciptakan suatu "free-market place of ideas", yaitu pasar yang identik dengan publik, dan tiap unsur publik memperoleh kedaulatan untuk menentukan produk media apa yang ingin dikonsumsi dan sekaligus akses ke media untuk berperan serta dalam diskursus terkait dengan kepentingan publik. Oleh sebab itu, para pengelola media selalu berdalih bahwa isi medianya semua tergantung dari apa yang diinginkan oleh pasar. Kata kunci yang selalu mereka tonjolkan adalah "leave things to the market".

Di tanah air, pertumbuhan infotainment diproduksi bersamaan dengan sinetron dan reality show, merupakan bukti nyata dari the logic accumulation atau dalam istilah Deddy N. Hidayat (2003) never ending circuit of capital accumulation: M-C-M (Money-Commodities-More Money). Kapitalisme yang mendasarkan diri pada rasionalitas instrumental memaksimalkan produksi-konsumsi dan keuntungan, dengan sistematis dan konsisten telah menciptakan struktur pasar yang "membungkam" media yang tidak mengikuti kaidah pasar. Oleh sebab itu, dengan tujuan akumulasi modal, industri televisi menciptakan selera pasar sambil menyatakan inilah "selera pasar" dan memaksa stasiun televisi mengakui dan mengakumulasi program sejenis, disaat bersamaan menyeimbangkan program lain. Sinetron reality show dan aneka kontes di televisi sangat membutuhkan infotainment, demikian juga sebaliknya.

Sebenarnya, pasar merupakan sebuah konstruksi sosial yang melibatkan suatu proses interaksi kekuasaan dalam penggal periode sejarah tertentu. Kapan pun dan dimana pun relasi dan interaksi antara pelaku yang terjadi dalam sebuah pasar selalu melibatkan seperangkat regulasi, norma, dan ketentuan yang mencerminkan sejarah dari hubungan sosial di masa lalu. Berger dan Luckmann mengatakan bahwa proses konstruksi sebuah pasar berlangsung melalui suatu interaksi sosial dan proses tersebut merupakan proses dialektis yang berkesinambungan, yang menampilkan 3 bentuk realitas, yaitu subjective reality, symbolic reality, dan objective reality serta melibatkan 3 momen tindakan, yaitu: internalization, externalization, dan objectivation. (Hidayat, 2003: 15-16)

Objective reality merupakan suatu kompleksitas definisi realitas (termasuk ideologi dan keyakinan) serta rutinitas tindakan dan tingkah laku yang telah mapan terpola dalam pasar (tercakup di dalamnya adalah berbagai bentuk kelembagaan sosial dalam pasar), yang kesemuanya dihayati oleh individu secara umum sebagai fakta. Symbolic reality merupakan ekspresi simbolik dari apa yang dinilai sebagai "objective reality", yang antara lain berupa teks produk industri media atau representasi 
pasar, kapitalisme, dan sebagainya dalam media. Subjective reality merupakan konstruksi definisi realitas seputar pasar yang dimiliki individu dan dikonstruksi melalui proses internalization terhadap suatu objective reality. Tetapi, realitas subjektif yang dimiliki masing-masing individu itu pula yang menjadi basis untuk melibatkan diri dalam proses eksternalisasi atau proses interaksi sosial dengan individu lain dalam sebuah struktur sosial, yaitu individu yang terlibat di dalamnya secara kolektif berpotensi melakukan objectivication untuk memuncullkan sebuah konstruksi objective reality yang baru. Artinya, meskipun proses eksternalisasi tersebut mungkin hanya sekadar penguatan legitimasi atau reproduksi struktur tertentu yang telah dinilai sebagai objective reality, tetapi proses itu pun berpeluang untuk memunculkan proses mempertanyakan validitas objective reality tersebut beserta makna dari segala representasi simboliknya. Proses mempertanyakan validitas objective reality tersebut berpeluang memunculkan objective reality baru. Proses ini berlangsung dalam sebuah proses dialektika yang berkesinambungan.

Konstruksi pasar pemirsa Infotainment juga didasarkan pada proses dialektika yang dikemukakan oleh Berger dan Luckmann itu. Realitas objektif awal dari kemunculan infotainment adalah tuntutan dari regulasi pemerintah akan adanya suatu program dalam negeri untuk mengimbangi tayangan impor di stasiun televisi kita dan juga tuntutan pemilik modal untuk mendapatkan keuntungan. Ketidakmampuan memproduksi program lokal sendiri membuat stasiun televisi memberikan pada rumah produksi dan menerima apa pun yang dibuat oleh mereka, asalkan dapat memenuhi realitas obyektif tadi, yaitu memenuhi porsi tayangan lokal dan memperoleh keuntungan.

Isi infotainment menciptakan suatu keyakinan pada khalayak bahwa memang program tersebut mereka butuhkan, atau menjadi realitas objektif khalayak. Terpaan terus menerus dari infotainment menciptakan suatu realitas simbolik terhadap isi media, misalnya khalayak menjadi tergantung pada infotainment, khalayak akan merasa seolah isi dan bentuk infotainment memang merupakan apa yang dibutuhkan oleh mereka. Proses internalisasi dari tayangan infotainment yang homogen di semua station akan menciptakan suatu realitas subjektif pada diri khalayak bahwa memang infotainment adalah kebutuhan mereka, apalagi akhirnya mereka melakukan proses ekternalisasi dengan interaksi sosial membicarakan isi infotainment dengan orang lain di lingkungannya yang diterpa program ini sehingga menimbulkan suatu objektifikasi yang memunculkan suatu realitas objektif yang baru, yaitu kebutuhan akan infotainment dengan gosip terbaru.

\section{Kebebasan Pers dan Etika Jurnalistik}

Banyak insan pers yang didukung elemen masyarakat mengidentikkan kebebasan pers sebagai kebebasan tanpa batas. Hal ini karena setelah munculnya Undang-undang Pers No. 40 tahun 1999 perkembangan media massa di Indonesia sedemikian pesat dan menumbuhkan persaingan antar media yang semakin ketat. Dalam persaingan yang ketat ini, biasanya orang tidak lagi memikirkan tentang misi dan idealisme pers. Yang ada pada benak pengelola media hanyalah tiras dan rating sehingga program semacam infotainment tetap dipertahankan, meskipun banyak yang mempertentangkan karena prinsip semua ditentukan oleh pasar.

Konsep infotainment sendiri awalnya berasal dari John Hopkins University, Baltimore, Amerika Serikat, yang berasumsi bahwa meski masyarakat membutuhkan informasi, tetapi tidak dapat menerima begitu saja sebuah informasi, apalagi jika informasi itu ditujukan untuk mengubah sikap negatif menjadi sikap positif manusia. Oleh sebab itu, diperlukan semacam pancingan khusus untuk menarik perhatian masyarakat, yaitu dengan menyisipkan unsur hiburan (entertaiment) yang menarik perhatian masyarakat di tengah penyampaian informasi tersebut. Dari sinilah muncul istilah infotainment, yaitu kemasan acara yang bersifat informatif namun dikemas dan disisipi dengan hiburan untuk menarik perhatian khalayak sehingga informasi sebagai utamanya dapat diterima dengan mudah oleh khalayak.(Syahputra, 2006: 66-67). 
Infotainment pada dasarnya adalah jenis soft journalism atau soft news yang berkembang di Amerika Serikat. Kategori ini bukan hanya menampilkan informasi dunia hiburan semata, tapi beraneka ragam berita dari olahraga, politik, sosial budaya, dan kriminal, yang dikemas menjadi lebih lunak dan menghibur. Namun di Indonesia, isinya lebih pada berita sensasional dari kehidupan selebritas dan tokoh publik, dengan dalih memenuhi selera pasar. Dalam perkembangannya, bahkan infotainment makin menukik pada kehidupan pribadi subjek sekaligus objek beritanya yang diungkap secara transparan, bahkan benar-benar "menelanjangi" objek berita. Etika jurnalistik pun banyak dilanggar, misalnya dengan penggunaan kamera tersembunyi atau melakukan penyadapan atau perekaman ilegal, seperti halnya dilakukan para paparazzi. Bahkan, beberapa infotainment sering mencari-cari topik yang cenderung bukan merupakan realita asalkan program acaranya punya isi tentang kisah seorang selebritas. Syaiful Bayan, produser sejumlah tayangan infotainment berpendapat bahwa kesalahan fatal yang terjadi dalam infotainment adalah kurangnya pengetahuan wartawan akan dunia selebritas. Sebagian besar dari mereka hanya terpaku pada apa yang terjadi di lapangan dan jarang melakukan metode in-depth atau melakukan investigasi mendalam akan topik atau tokoh yang diangkatnya (Sumiaty, 2006: 29).

Berbicara tentang etika dan profesionalisme jurnalis, Shoemaker dan Reese (1996) dalam teori hirarki, pengaruhnya memang menyatakan bahwa ada tingkatan-tingkatan yang mempengaruhi isi media. Mulai dari tingkatan individu jurnalis hingga ke tingkat ideologi media. Dalam tingkatan yang paling inti, pengaruh individu pekerja media merupakan inti dari bagaimana isi media yang akan keluar dan jadi konsumsi khalayak. Tahap ini sangat dipengaruhi oleh faktor pendidikan, pengalaman, kesukuan, agama, gender, dan sikap personal dan profesional individu terhadap peristiwa yang akan dilaporkan. Dalam hal perekrutan jurnalis yang dapat bekerja dalam industri infotainment, rupanya pihak rumah produksi tidak terlalu mensyaratkan pendidikan jurnalistik. Berdasarkan pengamatan penulis dari milis Milis Loker (Lowongan Kerja) Media Massa Audio-Visual yang ada di yahoogroups, maupun di jejaring sosial Facebook, persyaratan untuk menjadi reporter infotainment tidak diwajibkan berlatar belakang pendidikan jurnalistik. Beberapa lowongan untuk video journalist pun hanya dapat mengoperasikan alat perekam tertentu. Demikian pula untuk lowongan Koordinator Liputan tak mensyaratkan pendidikan dan pengalaman yang memadai.

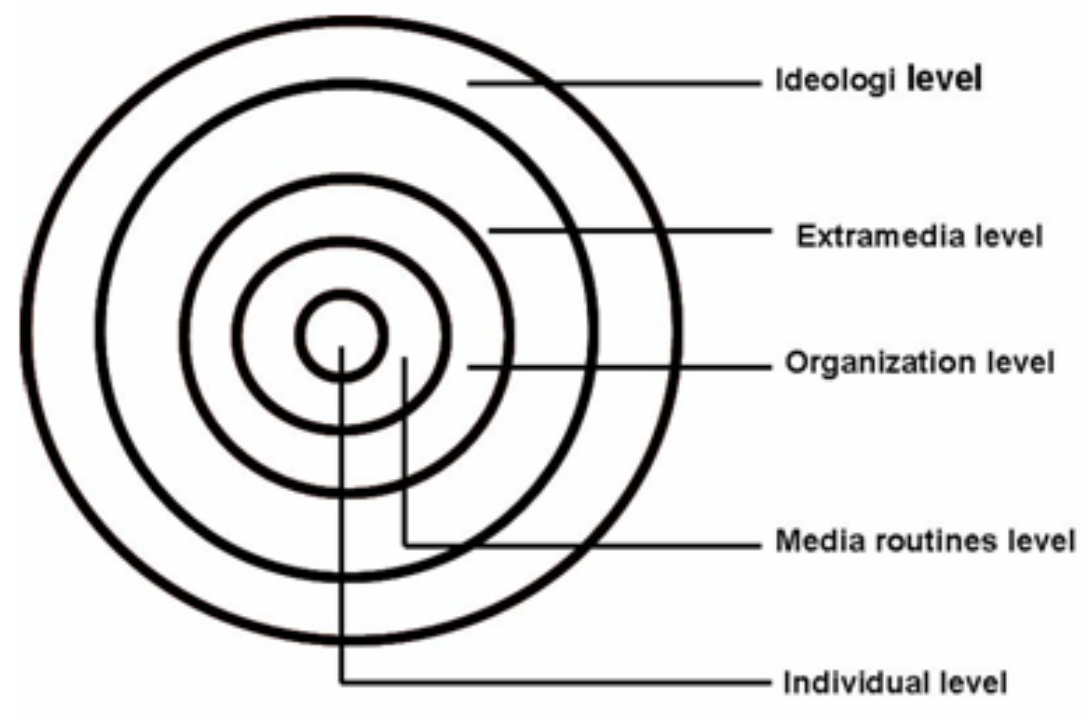

Gambar 1 Hierarchy of Influence - Shoemaker dan Reese (1996) 
Pada tahap rutinitas media, terkait dengan rutinitas yang biasa dilakukan media untuk mengolah berita yang masuk dari berbagai pintu berita. Setiap media biasanya berbeda dalam menentukan suatu berita. Ukuran layak atau tidaknya suatu berita dapat dipublikasikan, biasanya ditentukan oleh rutinitas sehari-hari dan menjadi prosedur standar seperti rapat redaksi. Di dalam kerja rutin infotainment yang harus hadir setiap hari, bahkan beberapa infotainment harus tayang dalam tiga kali sehari dengan info yang berbeda, tenggat (deadline) merupakan hal yang mempengaruhi isi dan kualitas berita yang disampaikan oleh infotainment.

Pada tahap organisasi media, tujuan organisasi, yaitu mendapatkan profit, seringkali memberi pengaruh pada isi berita. Pengelola media dan wartawan bukanlah satu-satunya yang paling menentukan isi berita. Mereka hanya pekerja media yang terkadang harus patuh pada peraturan perusahaan media. Oleh sebab itu, pada tahap organisasi terjadi dialektika mikro antara kepentingan perusahaan dengan idealisme jurnalis. Dalam infotainment, terlihat makin sensasional sebuah berita akan semakin tinggi nilai jualnya karena makin banyak khalayak yang menonton, otomatis rating akan semakin meningkat sehingga demi mewujudkan tujuan organisasi untuk mendapatkan profit seringkali idealisme jurnalis sengaja diabaikan.

Pada tahap ekstra media, terdapat berbagai unsur yang mempengaruhi isi media mulai dari sumber berita, para pengiklan, kelompok kepentingan, pemerintah, lingkungan media, teknologi, kompetitor, dan khalayak (Shoemaker \& Reese, 1996: 270). Dalam kasus infotainment yang biasanya diproduksi oleh rumah produksi yang berada di luar media televisi, maka pengaruh stasiun televisi yang menyewa mereka amat menentukan. Rumah produksi dituntut untuk mengisi airtime stasiun televisi. Jika tidak, kontraknya akan diputus oleh stasiun televisi dan digantikan dengan rumah produksi lain. Sementara itu, pengaruh para pemasang iklan berkaitan dengan rating. Makin tinggi rating, akan makin banyak iklan yang masuk. Rating sendiri bisa didapat jika infotainment bisa mendapatkan suatu berita yang eksklusif. Oleh sebab itu, seringkali infotainment justru mencari-cari hal-hal yang menarik dari kehidupan para selebritas. Sementara khalayak dianggap satu hal yang paling penting dalam mempengaruhi isi media karena media punya fungsi pelayanan pada kebutuhan khalayak. Namun, dalam kasus infotainment jika kita mengacu pada teori Berger \& Luckmann yang telah disebutkan sebelumnya, media justru mengonstruksi kebutuhan khalayak, kebutuhan akan gosip kehidupan para selebritas, dan kebutuhan ini dipelihara untuk keuntungan media, termasuk rumah produksi dan para pemasang iklan.

Tahap terakhir adalah tahap ideologi. Ideologi merupakan faktor ekstrinsik yang mempengaruhi isi media. Ideologi sendiri terkait dengan mekanisme simbolik, yang berfungsi sebagai kekuatan kohesif dan terpadu pada masyarakat. Dengan adanya pengaruh ideologi, media massa terlihat mempropagandakan ideologi mereka serta mengatur kealamian ideologi tersebut (Shoemaker \& Reese, 1996: 221). Louis Althusser menjelaskan ideologi sebagai sesuatu yang dibebankan secara langsung kepada kelompok yang tak berdaya oleh kelompok yang mempunyai kekuasaan untuk melanggengkan kekuasaan. Suatu ideologi bekerja atau berfungsi dengan mengambil individu dan menuntut mereka sebagai subjek-subjek di dalam kerangka ideologi (Strinati, 2003: 174). Di dalam kasus infotainment, ideologi yang bermain adalah ideologi pemilik stasiun televisi, yaitu ideologi neoliberalisme, bahwa semakin kuat pasar berperan, maka pers akan semakin bebas; dan semakin bebas pers, maka khalayak akan makin bebas memilih isi media. Dengan kata lain, bahwa orientasi pemilik media adalah pada pasar, dalam hal ini pada perolehan profit yang didapat dari pasar (pasar pengiklan dan pasar khalayak). Kebebasan pers disini adalah semata untuk mendukung ideologi pemilik media, yaitu untuk mendapatkan profit. Oleh sebab itu, para rumah produksi yang disewa stasiun televisi tak kuasa dan mau tak mau harus mengikuti ideologi tersebut. Akibatnya juga, pemilik rumah produksi membebani para pekerja infotainment dengan ideologi tersebut.

Sementara itu, berbicara tentang apakah berita yang disampaikan program infotainment sudah sesuai dengan etika jurnalistik atau tidak, maka kita harus mengupasnya dari konsep etika. Konsep etika sendiri, seperti dikatakan oleh Altschull merupakan kajian terhadap nilai moral dan prinsip 
belajar benar atau salah. Pada awalnya, konsep etika jurnalistik sangat berperan untuk memberikan pelayanan kemanusiaan (fungsi humanisme), ketimbang mencari tujuan jurnalistik itu sendiri. Etika dalam jurnalistik sangat berperan dalam menentukan, apakah jurnalis berdampak pada isi berita media. Beberapa jurnalis menganggap enteng masalah etika dan menyamakannya dengan obyektifitas (Syahputra, 2006: 43). Apabila mereka sudah menganggap bahwa peristiwa yang diliputnya objektif karena sudah menampilkan narasumber, maka mereka berpikir bahwa mereka sudah melakukan etika jurnalistik.

Hingga kini, istilah jurnalistik infotainment masih menyisakan berbagai persoalan dilematis. Selain PWI, sejumlah organisasi jurnalis menolak memasukkan kerja infotainment ke dalam kerja jurnalistik, meskipun dalam peringatan Hari Pers Nasional 9 Februari 2005, para pekerja infotainment telah dianggap sebagai wartawan. Hal ini karena ulah sejumlah jurnalis infotainment yang sering tidak mengindahkan etika dalam menggali informasi pada narasumber. Standar profesionalime jurnalis dan standar operasional dalam menentukan kelayakan berita seakan tidak diindahkan oleh mereka sehingga banyak yang tidak menganggap mereka sebagai insan pers atau jurnalis pers.

Secara umum, prinsip kode etik jurnalistik mengandung kebenaran (truthfulness) informasi, kejelasan (clarity) informasi, pembelaan atas hak publik, responsibilitas dalam membentuk opini publik, standar pengumpulan dan penyiaran informasi serta respek pada integritas sumber (Syahputra, 2006). Di dalam Kode Etik Jurnalis Televisi pun pada pasal 5 ayat a, dikatakan bahwa jurnalis televisi harus selalu mengevaluasi informasi semata-mata berdasarkan kelayakan berita, menolak sensasi, berita menyesatkan, memutarbalikkan fakta, fitnah, cabul, dan sadis (Tebba, 2008).

Seorang jurnalis infotainment sudah sewajarnya harus mengikuti kaidah tersebut dalam meliput dan menyiarkan suatu berita. Masalahnya, para jurnalis infotainment tidak memenuhi kaidah tersebut, mengingat sepak terjang mereka dalam menggali "gosip” seputar artis dan selebritas yang terkadang seperti diada-adakan, direkayasa sehingga menjadi suatu berita yang sensasional.

Jika memang jurnalis infotainment dianggap belum atau tidak mengindahkan kaidah di atas, lalu akan muncul pertanyaan, bagaimana cara mengatur agar mereka bisa bekerja layaknya seorang jurnalis pers yang mengindahkan etika jurnalistik tentang kebenaran, kejelasan, pembelaan atas hak publik, dan sebagainya itu.

\section{Menata Profesionalisme Jurnalistik Infotainment}

Untuk mewujudkan infotainment yang beretika, harus dimulai dari penataan dalam industri infotainment sendiri, yaitu dengan menyadarkan para pekerja infotainment bahwa untuk menjadi profesional terkadang memang harus menapaki sejumlah kesalahan. Namun, kesalahan itu akan menjadi kesalahan besar jika mereka tidak sadar bahwa mereka telah melakukan kesalahan. Pekerja infotainment tidak boleh beralasan bahwa apa yang mereka lakukan adalah kerja jurnalistik infotainment. Jika mereka ingin dianggap sebagai seorang jurnalis, maka mereka harus mengikuti kaidah etika jurnalistik yang umum dilakukan.

Mereka harus dapat membedakan, mana wilayah publik dan mana wilayah pribadi. Mereka harus menyadari bahwa dengan menjadi seorang selebritas bukan berarti para selebritas tak boleh mempunyai rahasia yang menjadi konsumsi pribadi mereka. Tidak semua sisi kehidupan selebritas pantas untuk menjadi konsumsi publik. Misalnya, dalam kasus peselingkuhan seorang selebritas dengan selebritas lain. Jika pasangan sang selebritas yang selingkuh tadi tidak mau memberikan komentar tentang perselingkuhan pasangannya itu, pekerja infotainment tidak boleh memaksa dia untuk menjawab dengan alasan kepentingan publik. Jangankan pasangannya, untuk selebritas yang melakukan perselingkuhan pun jika tidak mau berkomentar harusnya mereka tak boleh memaksa ia berbicara, apalagi hingga "menongkrongi" rumah atau kantor dari selebritas tersebut sehingga menganggu kehidupan sehari-hari sang selebritas dan juga lingkungan sekitar. 
Dalam konteks menata profesionalisme jurnalis, ada dua konsep yang berbeda, yaitu "mulai dari diri sendiri” dan "menjadi diri sendiri". Mulai dari diri sendiri berarti mengerti atribut profesi yang digeluti. Memilih profesi sebagai jurnalis berarti harus menjalani tata aturan yang ada dalam dunia jurnalistik. Sementara menjadi diri sendiri lebih pada penonjolan karakter kepribadian. Biasanya seorang jurnalis akan mulai dari diri sendiri dulu, menata profesionalismenya sesuai tata aturan yang berlaku, baru kemudian menjadi diri sendiri, yaitu memegang teguh prinsip memberikan informasi yang berhubungan dengan kepentingan publik.

Pembenahan manajemen redaksional infotainment juga harus dilakukan. Ada baiknya kualitas dari pekerja infotainment, mulai dari reporternya hingga ke gatekeeper ditingkatkan dengan pemberian materi etika jurnalistik dan konsep dasar pemberitaan sehingga para pekerja infotainment bisa menyinergikan antara kepentingan ekonomi pemilik modal dan kepentingan publik akan informasi yang bermutu dan mendidik masyarakat. Para pekerja infotainment, khususnya pihak pengelola rumah produksi infotainment harus menyadari kekeliruan yang selalu mereka lakukan seperti dikatakan Iswandi Syahputra (Syahputra, 2006: 169-197) bahwa ada 9 kekeliruan yang selalu dilakukan oleh pekerja infotainment, yaitu pertama, gosip sebagai berita. Gosip bukanlah berita dan berita tidak bisa dibuat menjadi gosip; kedua, mencari-cari kesalahan orang. Berbeda dengan bersikap kritis yang didorong pada pencarian fakta baru, informasi baru, atau mencari berita di balik berita; ketiga, pemaksaan. Jika seseorang menolak untuk menjawab pertanyaan, tidak boleh memaksa untuk menjawab; keempat, dramatisasi. Diperbolehkan, namun harus dalam bingkai etika dan norma serta fakta yang ada; kelima, opinisasi. Bukanlah opinisasi sistemik, yaitu praktik pembentukan opini yang diproduksi secara sadar, tendensius, dan berpretensi yang secara langsung dibacakan oleh presentasi melalui berbagai narasi; keenam, penggunaan media. Sebagian besar infotainment diproduksi bukan oleh media yang menyiarkan sehingga banyak yang beranggapan bahwa produk infotainment juga merupakan produk media massa itu; ketujuh, mengumbar privasi. Sudah menjadi trade mark infotainment karena infotainment gagal menggunakan atau menggali perspektif lain dari sosok selebritas; kedelapan, mengancam. Pekerja infotainment sering melakukan pemboikotan terhadap selebritas yang mereka anggap tidak mau bekerja sama; serta kesembilan, penggunaan istilah. Begitu mudahnya infotainment menobatkan seseorang menjadi selebritas, meskipun yang menjadi selebritas hanyalah istri/suaminya, juga kerancuan profesi jurnalis dan anchor pada tayangan infotainment.

\section{SIMPULAN}

Infotainment bagaikan buah simalakama. Jika dihilangkan, maka akan mematikan sejumlah industri, yang berarti akan banyak pengangguran terjadi. Selain itu, para artis dan selebritas pun tak mempunyai sarana untuk mempromosikan diri mereka. Memang terkadang artis dan selebritas menggunakan program ini untuk mempopulerkan nama. Bahkan, ada yang dengan sengaja menebar isu yang negatif tentang dirinya sendiri agar diliput oleh infotainment. Di lain pihak, jika infotainment tetap saja berlangsung seperti ini, maka akan menciptakan suatu masyarakat yang bodoh dan tidak kritis karena terlena dengan informasi yang tidak bermutu.

Oleh sebab itu, perlu segera diwujudkan suatu regulasi tentang penataan isi media yang lebih spesialis. Meski Undang-undang Pers yang berlaku sekarang sudah dianggap Lex Spesialis, namun masih diperlukan lagi suatu regulasi yang secara detail mengatur apa yang boleh dan apa yang tidak boleh ditayangkan atau diberitakan oleh media massa. Bukan hanya sekedar kode etik jurnalistik yang memang pembuatannya adalah kesepakatan antara para pihak yang tergabung dalam industri televisi. Tampaknya kita tak bisa mengandalkan kontrol informal ataupun self regulation dari organisasi media atau suatu badan independen seperti KPI atau Dewan Pers karena nuansa ekonomi politik masih mendominasi tayangan program ini. 
Ada baiknya dilakukan amandemen terhadap Undang-undang Pers supaya lebih Lex Spesialis lagi, dengan memasukkan pasal yang membela kepentingan publik yang selama ini hanya masuk dalam kode etik jurnalistik. Ada banyak kasus media yang berhubungan dengan hukum akhirnya harus diselesaikan dengan menggunakan KUHP karena dalam Undang-undang Pers yang ada saat ini tidak diatur, atau bahkan diselesaikan dengan cara primitif seperti kasus Tempo dengan Tommy Winata, Khoe Seng Seng dengan PT Duta Pertiwi, dan kasus Luna Maya yang melampiaskan kemarahan terhadap wartawan ke jaringan Twitter hingga berakhir di meja hijau dengan menggunakan Undangundang ITE yang tidak mengelaborasi kepentingan publik. Padahal, jika pasal 5 ayat a Kode Etik Jurnalis Televisi juga dimasukkan ke dalam Undang-undang Pokok Pers, maka Luna Maya tak perlu "uring-uringan" melalui jejaring sosial Twitter, dan tak perlu terkena pasal dari Undang-undang ITE karena insiden "kamera infotainment" itu tak akan terjadi akibat para jurnalis infotainment mengerti bahwa mereka akan terjerat hukum.

\section{DAFTAR PUSTAKA}

Hidayat, D. N. (2003). Fundamentalisme pasar dan konstruksi sosial industri penyiaran: kerangka teori mengamati pertarungan di sektor penyiaran. Dalam Konstruksi Sosial Industri Penyiaran, Jakarta: Departemen Ilmu Komunikasi FISIP UI.

Loker (Lowongan Kerja) Media Massa Audio-Visual. Retrieved from http://www.facebook.com/group.php?gid=53122017404

Milis Loker (Lowongan Kerja) Media Massa Audio-Visual. Retrieved from http://finance.groups.yahoo.com/group/Loker_Media_Massa_Audio_Visual/

Panjaitan, H.P., dan Amir E. S. (2006). Undang-undang pers memang lex spesialis, Jakarta: Badan Bantuan Hukum dan Advokasi Kemerdekaan Pers Serikat Penerbit Surat Kabar.

Shoemaker, P., and Reeese, S. D. (1996). Mediating the message: theories of influences on mass media content, New York: Longman.

Soemardjo, S. (2006). Infotainment: antara produksi, rating, dan iklan. Dalam Observasi. Menggugat infotainment, (4) 2, 2006, Bandung: BP2i.

Sumiaty, N. (2006). Pengabaian etika jurnalistik dalam infotainment. Dalam observasi. Menggugat infotainment, 4 (2), 2006, Bandung: BP2i.

Syahputra, I. (2006). Jurnalistik infotainment: kancah baru jurnalistik dalam industri televisi, Yogyakarta: Pilar Media

Tebba, S. (2008). Etika media massa, Banteng: Pustaka Irvan. 